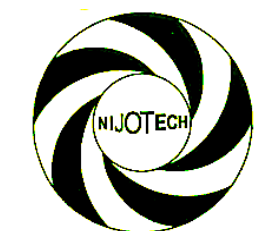

Nigerian Journal of Technology (NIJOTECH)

Vol. 39, No. 1, January 2020, pp. 196 - 202

Copyright@ Faculty of Engineering, University of Nigeria, Nsukka,

Print ISSN: 0331-8443, Electronic ISSN: 2467-8821

www.nijotech.com

http://dx.doi.org/10.4314/njt.v39i1.22

\title{
ANALYSIS OF FACTORS THAT INFLUENCE THE CALORIFIC VALUE OF MANGROVE WOOD FOR ELECTRICITY GENERATION USING SPLIT- SPLIT PLOT DESIGN
}

\author{
L. A. Omidih ${ }^{1}$ and S. A. Omotehinse ${ }^{2, *}$ \\ 1, Department of Mechanical Engineering, Delta State Polytechnic, Oghara, Delta State, nigeria \\ 2, Department of Production Engineering, UniVERSity of Benin, BENIN City, Edo STATE, NIGERIA \\ E-mail addresses; 1 lomidih@yahoo.com, 2 drsamayodeji@gmail.com
}

\begin{abstract}
The issue of energy shortage in Nigeria has been a concern for both the Nigerian government and the people for the past four decades. In many third world countries and indeed many parts of Africa, Nigeria inclusive, electricity is abysmally in short supply. This is somehow due to over dependence on fossil fuels which accounts for greater part of the power generation but with an unreliable supply chain. This study seeks to apply Split-Split plot experimental design as statistical tool to analyze factors that influence the calorific value of mangrove wood during combustion for electricity generation. The combustion process was carried out at the National Centre for Energy and Environment, University of Benin. Each of the wood samples was pulverized to enable easy combustion. Bomb calorimeter was used to carry out the test on the various pulverized wood samples. The calorific value of each sample was collected and recorded in three replications. The result of the study shows that the raw materials location has differential treatment effect on the calorific value of the raw material type employed. It was discovered that the differential treatment effect produced by the raw materials type is largely due to the location of the raw materials. The result obtained from the analysis also shows interaction between the raw materials location and the different raw material types to influence the calorific value of the white mangrove, red mangrove and rubber wood used in this study.
\end{abstract}

Keywords: Energy, Electricity generation, Wood waste, Fossil fuel, Split-Split Plot.

\section{Nomenclature}

$X$. This is an operation indicating interaction between the blocks and the treatments.

$A$ Raw materials (wood) location

$B$ Raw materials (wood) type

$C$ Raw materials (wood) location $\times$ raw materials (wood) type interaction

$\mu$ Overall population mean

$\alpha_{i}$ Model block parameter for raw materials (wood) location

$\alpha$ Confidence level

$\beta_{j}$ Model treatment parameter for raw materials (wood) type $(\alpha \beta)_{i j}$ Model block for raw materials (wood) location $\times$ raw materials (wood) type interaction

$\varepsilon_{(i j k l)} \quad$ Error component

$S S_{E} \quad$ Sum of squares for error

$S S_{T}$ Sum of squares for total

$S S_{A}$ Sum of squares for wood location

$S S_{B}$ Sum of squares for wood type

$S S_{C}$ Sum of squares for wood location $\times$ wood type interaction

Error Discrepancy or deviation from mean value

$F_{\text {cal }} \quad$ Fisher's ratio (calculated value)

* Corresponding author, tel: +234 8035971630 


$$
\begin{aligned}
& F_{\text {tab }} \quad \text { Fisher's ratio (tabular value) } \\
& H_{0}, \mathrm{H}_{1} \quad \text { Null, alternative hypothesis }
\end{aligned}
$$

\section{INTRODUCTION}

The issue of energy shortage in Nigeria has been a concern for both the Nigerian government and the people for the past four decades. While other countries with similar problems have long overcome the predicament, Nigerians still live in darkness. Some businesses have relocated from the country as a result of inability of the national power supply to meet their demand while homes have had to adapt to the epileptic power supply or in some cases total blackout. The main energy challenges that face Nigeria presently is how to increase energy supplies to meet the needs of its growing population. Energy has a major impact on every aspect of our socioeconomic life. It plays a vital role in the economic, social and political development of any nation Nigeria inclusive. Inadequate supply of energy restricts socioeconomic activities, limits economic growth and adversely affects the quality of life. The Niger Delta region is home to most of the Nigerian oil resources, but with oil pipelines being vandalized, as well as sabotage and abductions, the disruption caused has led to many power generating stations losing their supply of natural gas resulting to dramatically decreasing and even completely halting power generation. Considering the non-renewable nature of fossil energy, coupled with never ending agitation for resource control in the Niger Delta regions, the solution to power problems in Nigeria may be in a new renewable option. Biomass resources such as municipal solid waste, animal wastes, agricultural crops and residues, as well as other forestry resources, are very common in Nigeria. Given that they are widely available, especially wood waste, there is a large potential for their use in producing biofuel. The use of biomass can, however, reduce the instability in the power sector.

Research interest on energy has built up in the last two decades. Some of the works done in the past include: Etukudor et al. [1] who carefully analyzed each segment of the Nigerian Electricity Supply Industry (NESI) and successfully identified the rootcauses of constant power outages in the country which has led to a high unreliability of supply, with a view to proffering workable solutions. Emodi and Ebele [2] reviewed the various policies and strategies promoting renewable energy development around the world. The success and failures of each country and regions were examined through a case study to learn some valuable lessons and derive useful implications for the development of renewable energy in Nigeria. The study initially reviewed the current renewable energy policies and identified the barriers to the development of renewable energy technology in Nigeria. Edomah [3] analyzed the barriers to sustainable energy development in Nigeria. The author concludes by highlighting some key policies that could help address some of the identified barriers in order to ensure a secured sustainable energy future for Nigeria. Other notable works are [4-7]. Researches on energy generation using wood as source of heat and their methods of analysis were reviewed by [8-11]. Similar research include: [12-15].

The method proposed in this study is the use of splitsplit plot experimental design. This method was carefully chosen because of its insightful capacity to handle both individual and collective effect of several factors simultaneously in an attempt to ascertain their various effects. The resulting experimental design presents a unique integration of response variables that requires the development of a special statistical model to handle. The aim of this study therefore, is to analyze factors that influence the calorific value of mangrove wood during combustion for electricity generation using the split-split plot experimental design.

\section{MATERIALS AND METHODS}

\subsection{Materials}

Two types of mangrove wood namely White Mangrove and Red Mangrove together with Rubber Wood that served as Control were sourced from various locations such as: Warri, Abigboro (Sapele), Bayelsa and Abonema (Rivers State) in Nigeria. The equipment used to carry out the combustion test on those woods is Bomb Calorimeter. The test was carried out in National Centre for Energy and Environment, University of Benin. Each of the wood samples was pulverized to enable easy combustion. The principal factors identified to influence the calorific value of the mangrove woods for electricity generation are raw materials location and raw materials type (wood location and wood specie).

\subsection{Methods}

Split-Split plot experimental design was used as statistical tool to analyze factors that influence the 
calorific value of mangrove wood during combustion process for electricity generation. The Calorific value of the different wood species from the different location was determined during the combustion process. Three replicates of each measurement (Calorific value) were taken and the average computed. The response variables were recorded and depicted in Figures 1 and 2. Thereafter, statistical computations were undertaken and results summarized in ANOVA result format shown in Table 1.

\subsubsection{Model Development}

The model developed for the split-split plot experimental design analysis is given as:

$X_{i j k}=\mu+\alpha_{i}+\beta_{j}+(\alpha \beta)_{i j}+\varepsilon_{i j(k)}\left\{\begin{array}{c}I=1,2,3,4 \\ J=1,2,3 \\ K=1,2,3\end{array}\right\}$

where, $X_{i j k}-$ Response Variable

$i=$ raw materials (wood) location

$j=$ raw materials $($ wood $)$ type

$k=$ replications

\subsubsection{Computational Statistics for the Split- Split Plot design}

1. Sum of squares for total ( $\mathrm{SS}_{\mathrm{T}}$ )

$S S_{T}=\sum_{i=1}^{I=4} \sum_{j=1}^{J=3} X_{i j k}^{2}-\frac{X_{\ldots}^{2}}{I J K}$

2. Sum of squares for raw materials (wood) location $\left(\mathrm{SS}_{\mathrm{A}}\right)$

$S S_{A}=\sum_{i=1}^{I=4} \frac{X_{i . .}^{2}}{J K}-\frac{X_{\ldots}^{2}}{I J K}$

3. Sum of squares for raw materials (wood) type $\left(\mathrm{SS}_{\mathrm{B}}\right)$

$S S_{B}=\sum \frac{X_{. j .}^{2}}{I K}-\frac{X_{\ldots}^{2}}{I J K}$

4. Sum of squares for raw materials (wood) location $\times$ raw materials (wood) type interaction $\left(\mathrm{SS}_{\mathrm{AB}}\right)$

$$
S S_{A B}=\sum_{i=1}^{I=4} \sum_{i=1}^{J=3} \frac{X_{i j .}^{2}}{K}-\sum_{j=1}^{I=4} \frac{X_{i . .}^{2}}{J K}-\sum_{j=1}^{J=3} \frac{X_{. j .}^{2}}{I K}+\frac{X_{\ldots .}^{2}}{I J K}
$$

5. Error sum of squares $\left(\mathrm{SS}_{\mathrm{E}}\right)$

$$
S S_{E}=S S_{T}-S S_{A}-S S_{B}-S S_{A B}
$$

\section{RESULTS AND DISCUSSION}

Figure 1 describes the crafting of the analytical abstract experimental design using dot notation to represent the response variables. On the other hand, Figure 2 illustrates self-same design with response variables in each cell represented as numerical observations.

\subsection{Statistical Computations}

1. Sum of squares for total (SST)

$$
S S_{T}=\sum_{i=1}^{I=4} \sum_{j=1}^{J=3} X_{i j k}^{2}-\frac{X_{\ldots}^{2}}{I J K}
$$

2. Sum of squares for raw materials (wood) location $\left(\mathrm{SS}_{\mathrm{A}}\right)$

$$
S S_{A}=\sum_{i=1}^{I=4} \frac{X_{i . .}^{2}}{J K}-\frac{X_{\ldots}^{2}}{I J K}
$$

3. Sum of squares for raw materials (wood) type $\left(\mathrm{SS}_{\mathrm{B}}\right)$

$$
S S_{B}=\sum \frac{X_{. j .}^{2}}{I K}-\frac{X_{\ldots}^{2}}{I J K}
$$

4. Sum of squares for raw materials (wood) location $\times$ raw materials (wood) type interaction $\left(\mathrm{SS}_{\mathrm{AB}}\right.$ )

$$
S S_{A B}=\sum_{i=1}^{I=4} \sum_{i=1}^{J=3} \frac{X_{i j .}^{2}}{K}-\sum_{j=1}^{I=4} \frac{X_{i . .}^{2}}{J K}-\sum_{j=1}^{J=3} \frac{X_{. j .}^{2}}{I K}+\frac{X_{\ldots .}^{2}}{I J K}
$$

5. Error sum of squares $\left(\mathrm{SS}_{\mathrm{E}}\right)$

$$
S S_{E}=S S_{T}-S S_{A}-S S_{B}-S S_{A B}
$$

The above computational data is summarized and represented in table 1. 


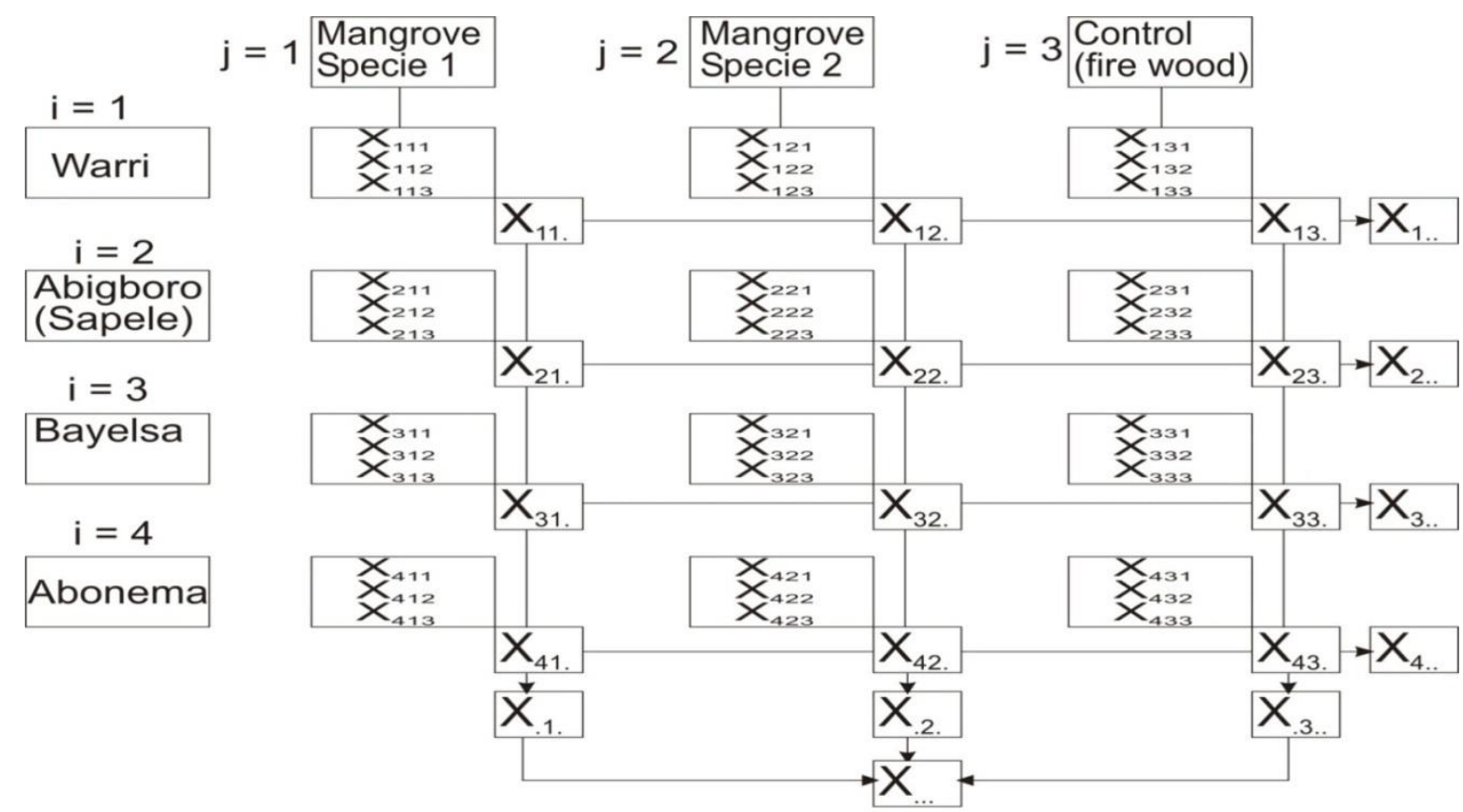

\footnotetext{
$i=4$ Wood Location

$j=3$ Wood type

$k=3$ Replications

$X_{i j k}=$ Response variable
}

Figure 1: Analytical abstract design for mangrove wood combustion

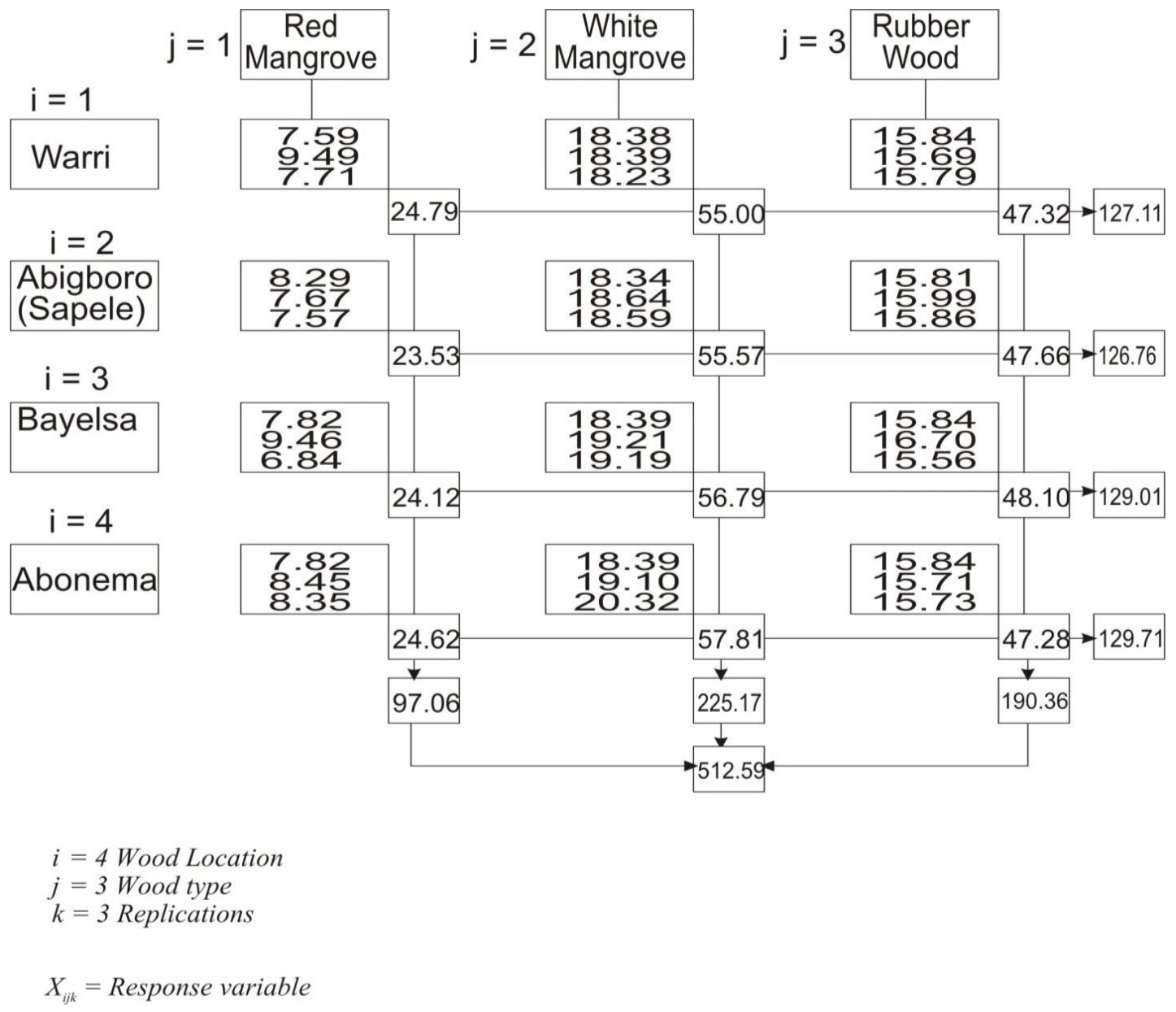

Fig. 2: Numerical Abstract Design for Mangrove wood combustion 
Table 1: ANOVA result for Wood combustion

\begin{tabular}{|c|c|c|c|c|c|c|}
\hline $\begin{array}{l}\text { Sources of } \\
\text { Variation }\end{array}$ & $\begin{array}{l}\text { Sum of } \\
\text { squares }\end{array}$ & $\begin{array}{l}\text { Degree of } \\
\text { freedom }\end{array}$ & $\begin{array}{l}\text { Mean sum } \\
\text { of squares }\end{array}$ & $\mathrm{F}_{\mathrm{cal}}$ & $\begin{array}{l}\mathrm{F}_{\mathrm{tab}} \\
\alpha=0.05\end{array}$ & Decision \\
\hline $\begin{array}{l}\text { Raw materials } \\
\text { location }(A)\end{array}$ & 0.69 & $(\mathrm{I}-1)=3$ & 0.23 & $\frac{M S_{A}}{M S_{E}}=0.59$ & $F_{3,24,0.05}=3.01$ & $\begin{array}{l}F_{c a l}<F_{t a b} \\
\text { Accept } \mathrm{H}_{0}\end{array}$ \\
\hline $\begin{array}{l}\text { Raw materials } \\
\text { (wood) type (B) }\end{array}$ & 731.36 & $(J-1)=2$ & 365.68 & $\frac{M S_{B}}{M S_{E}}=937.64$ & $F_{2,24,0.05}=3.40$ & $\begin{array}{l}F_{c a l}>F_{t a b} \\
\text { Reject } \mathrm{H}_{0}\end{array}$ \\
\hline $\begin{array}{l}\text { Raw materials } \\
\text { location } \times \text { Raw } \\
\text { materials }(\text { wood }) \\
\text { type }(A \times B)\end{array}$ & 1.36 & $\begin{array}{l}(\mathrm{I}-1)(\mathrm{J}-1) \\
=6\end{array}$ & 0.23 & $\frac{M S_{A B}}{M S_{E}}=0.59$ & $F_{6,24,0.05}=2.51$ & $\begin{array}{l}F_{c a l}<F_{t a b} \\
\text { Accept } \mathrm{H}_{0}\end{array}$ \\
\hline Error & 9.45 & $\begin{array}{l}\mathrm{IJ}(\mathrm{K}-1)= \\
24\end{array}$ & 0.39 & & & \\
\hline Total & 742.86 & $\begin{array}{l}\text { IJK-1 = } \\
35\end{array}$ & & & & \\
\hline
\end{tabular}

\subsection{Examination of block effect of raw materials location$$
H_{0}: \alpha_{i}=0, \mathrm{H}_{\mathrm{i}}: \alpha_{i} \neq 0
$$

Since $F_{\text {cal }}=0.59<F_{\text {table }}=3.01$, we lack sufficient evidence for us to reject the null hypothesis $H_{0} @ \alpha=0.05$. It was therefore concluded that the raw materials location have differential treatment effect on the calorific value of the raw material type (wood) employed.

\subsection{Examination of block effect of raw materials type}

$$
H_{0}^{\prime}: \beta_{j}=0, \mathrm{H}_{\mathrm{j}}^{\prime}: \beta_{i} \neq 0
$$

$\mathrm{F}_{\text {cal }}=937.64>\mathrm{F}_{\text {table }}=3.40$. This suggests that our experimental data do not provide enough proof for us to accept the null hypothesis $H_{0}^{1}$. The implication of this is that the differential treatment effect produced by the raw materials type (woods) is largely due to the location of the raw materials.

\subsection{Examination of raw materials location $\times$ raw materials type interaction}

$$
H_{0}{ }^{I I}:(\alpha \beta)_{i j}=0, \mathrm{H}_{\mathrm{j}}{ }^{I I}:(\alpha \beta)_{i j} \neq 0
$$

Since $F_{\text {cal }}=0.59<F_{\text {table }}=2.51$. We conclude that our experimental analysis provide paucity of evidence for us to reject the null hypothesis $H_{0}^{I I}$. This suggest that there appears to be interaction between the raw materials location and the different raw materials types to influence the calorific value of the white mangrove, red mangrove and rubber wood used in this study.

It is obvious from the preceding analysis that the split-split plot experimental design used is a robust statistical model that wields the profound capacity to handle both individual (wood location and wood type) and collective effect of several factors (the interaction of wood location and wood type) simultaneously in attempt to ascertain their various effects on the calorific value of mangrove wood during combustion for electricity generation.

From the experimental analysis discussed above as particularly seen in Figure 2, it was observed that white mangrove produced the highest calorific value than the other species of wood used. The implication of this is that the rate at which white mangrove dissipates heat energy for electricity is better than the others. This also suggests that it will produce steam at a much lesser time. It was also observed that the best location for the mangrove wood was Abonema, Rivers State. The white mangrove only grows in salt 
water. The salinity of the water in Abonema was high that is why the calorific value was higher than the others. The density per square meter in Abonema was higher than the other location which account for the result observed. Next to Abonema was Bayelsa State, this was because the water body where the mangrove wood grows is close to Abonema in Rivers State.

Our result shows that the raw materials location have differential treatment effect on the calorific value of the raw materials type (wood) employed. It was discovered also that the differential treatment effect produced by the raw materials type (woods) is largely due to the location of the raw materials and there appears to be interaction between the raw materials location and the different raw materials types to influence the calorific value of the white mangrove, red mangrove and rubber wood used in this study.

\section{CONCLUSION}

The researcher has been able to apply split-split plot experimental design that incorporated two principal factors (raw materials location and raw materials type) in one experimental setting in order to understand the dynamics of the mutual interaction of the aforementioned factors in influencing the calorific value of mangrove wood during combustion process for electricity generation. The author has identified the facts that wood specie per se is a crucial factor. Moreover, wood location and wood specie mutually act to affect the calorific value of mangrove wood during combustion process to produce quality heat energy.

\section{REFERENCES}

[1]. Etukudor, C., Abdulkareem, A., Ayo, O. "The Daunting Challenges of the Nigerian Electricity Supply Industry", Journal of Energy Technologies and Policy, Vol.5, No.9, 2015, pp 25-32.

[2]. Emodi, N.V. and Ebele, N. E. "Policies Enhancing Renewable Energy Development and Implications for Nigeria". Sustainable Energy, 4(1), 2016, pp 7-16.

[3]. Edomah, N. "On the path to sustainability: Key issues on Nigeria's sustainable energy development". Energy Reports, Volume 2, 2016, pp 28-34.
[4]. Aji, M.M., Gutti, B., Bitrus, K. Highina and Mustapha, Hussaini, A. "Challenges to Energy Sustainability in Nigeria as a developing nation and the way forward", Applied Research Journal, Vol.1, Issue, 2, 2015, pp.46-50.

[5]. Abdullahi, D., Suresh, S., Renukappa, S. and Oloke, D. "Key Barriers to the Implementation of Solar Energy in Nigeria: A Critical Analysis", 2nd International Conference on Green Energy Technology (ICGET 2017), IOP Conf. Series: Earth and Environmental Science, 83, 2017, 012015.

[6]. Usman, Z.G.and Abbasoglu, S. "An Overview Of Power Sector Laws, Policies and Reforms In Nigeria", Asian Transactions on Engineering, Volume 04 Issue 02, 2014, pp 6-12.

[7]. Onochie, U.P., Obanor, A., Aliu, S.A. "Electricity Crisis in Nigeria: The Way Forward", American Journal of Renewable and Sustainable Energy, Vol. 1, No. 4, 2015, pp. 180-186.

[8]. Akhator, E.P., Obanor, A. I., Ezemonye, L.I. "Electricity Generation in Nigeria from Municipal Solid Waste using the Swedish Waste to-Energy Model". J. Appl. Sci. Environ. Manage, Vol. 20 (3), 2016, 635 - 643.

[9]. Adeniji, O.A., Zaccheaus, O.S., Ojo, B.S., Adedeji, A.S. "Charcoal Production and Producers' Tree Species Preference in Borgu Local Government Area of Niger State, Nigeria", Journal of Energy Technologies and Policy, Vol.5, No.11, 2016, pp. 1-8.

[10]. Awoyemi, T.T., Amao, A.O and Fatogun, O. "Household Expenditure Pattern on Energy Consumption in Ibadan, Oyo State Nigeria", Journal of Economics and Rural Development, 15(1), 2016, 79-87.

[11]. Popoola, L., Gutti, B., Adeniran, J. A and Adeoye, B.K. "The potentials of waste-toenergy system in Nigeria: A study of pyrolysis conversion of wood residue to bio-oil in major cities of south-western Nigeria", Advances in Applied Science Research, 4(2), 2013, 243251.

[12]. Anyanwu, C.N., Ibeto, C.N., Eze, I.S., and Ezeoha, S.L. "Present and prospective energy use potentials of selected agricultural wastes in Nigeria", Journal of Renewable and Sustainable Energy, 5 032703-1- 032703-13, 2013.

[13]. Oluoti, K., Megwai, G., Pettersson, A., Richards, T. "Nigerian Wood Waste: A Dependable and Renewable Fuel Option for Power Production", World Journal of Engineering and Technology, 2, 2014, 234-248. 
[14]. Ujam, A. J. and Eboh, F. "Thermal Analysis of a Small-Scale Municipal Solid Waste-Fired Steam Generator: Case Study of Enugu State, Nigeria", Journal of Energy Technologies and Policy, Vol.2, No.5, 2012, 38-54.
[15]. Ujam, A.J., Eboh, F., Chime, T.O. "Effective Utilization of a Small-Scale Municipal Solid Waste for Power Generation", Journal of Asian Scientific Research, 3(1), 2013, 18-34. 